\title{
HUKUM KASIH: \\ LANDASAN BERSAMA AGAMA-AGAMA
}

\author{
Frits Octavianus Tatilu \\ Sekolah Tinggi Teologi Injili Indonesia (STTII) Jakarta
}

\begin{abstract}
This article which is entitled as "The Law of Love: A Joint Foundation of Religions focuses on how "The Law of Love" is able to be applied in the joint life of religions in Indonesia, especially as a joint foundation in the formulation of non-discriminatory policy be it in central government or in local government. Firstly, it will be discussed about the understanding of the Law of Love in Christian perspective, and then it will be also discussed about views of religions related with the Law of Love. The writer supposes that the law of love is able to be a joint foundation of religions, as well as be applied in the formulation of nondiscriminatory public policy.
\end{abstract}

KEYWORDS: the law of love, religions, joint foundation, discrimination.

ABSTRAK: Artikel yang berjudul "Hukum Kasih: Landasan Bersama Agama-agama ini fokus pada bagaimana "Hukum Kasih" dapat diterapkan dalam kehidupan bersama agama-agama di Indonesia, secara khusus sebagai landasan bersama perumusan kebijakan non diskriminatif baik di pemerintahan pusat maupun pemerintahan daerah. Pertama-tama akan dipaparkan mengenai pemahaman hukum kasih dalam perspektif Kristen, dan kemudian akan dipaparkan mengenai pandangan agama-agama terkait Hukum kasih. Penulis beranggapan bahwa hukum kasih dapat menjadi landasan bersama agama-agama, demikian juga dalam permusan kebijakan publik yang non diskriminatif. KATA-KATA KUNCl: hukum kasih, agama-agama, landasan bersama, diskriminasi. 


\section{Pendahuluan}

Reformasi mental yang diusung pemerintahan Presiden Joko Widodo dan Wakil Presiden Jusuf Kalla sepatutnya mendapat dukungan semua rakyat Indonesia. Reformasi mental yang dimaksud di sini adalah perubahan secara drastis untuk perbaikan mental atau watak masyarakat Indonesia dalam bidang sosial, politik dan agama. ${ }^{1}$ Sasarannya agar tujuan negara Indonesia tercapai, yaitu masyarakat yang adil, makmur dan sejahtera.

Tantangan dari program reformasi mental adalah masalah diskriminasi, baik karena agama, sosial dan budaya, karena itu diperlukan satu landasan yang kuat agar kebijakan-kebijakan pemerintah baik pusat maupun daerah yang terindikasi diskriminatif sepatutnya dienyahkan dari bumi Indonesia. Kajian ini akan memberikan satu landasan bagi kehidupan yang non-diskriminatif, yakni konsep Hukum Kasih sebagai landasan bersama agama-agama, dan demi hadirnya kebijakan-kebijakan publik yang non-diskriminatif.

\section{Kebijakan Diskriminatif}

Diskriminasi adalah pembedaan perlakuan terhadap sesama warga negara yang didasarkan suku, agama dan ras. ${ }^{2}$ Praktik diskriminasi ini cenderung memecah-belah persatuan dan kesatuan sebuah bangsa. Karena diskriminasi, masyarakat terbelah menjadi dua yaitu masyarakat mayoritas dan masyarakat minoritas. Dan cenderung masyarakat mayoritas mendiskriminasi masyarakat minoritas.

Salah satu kasus diskriminasi yang belum lama terjadi di Indonesia adalah yang menimpa gubernur DKI Jakarta, Basuki Tjahaja Purnama atau yang lebih populer dengan nama panggilan "Ahok". ${ }^{3}$ Ahok dijadikan terdakwa kasus penistaan agama setelah video pidato

Kamus Besar Bahasa Indonesia (Balai Pustaka, 2002), 733, 939.

Kamus Besar Bahasa Indonesia (Balai Pustaka, 2002), 269.

Tempo.co, 10 Mei 2017. Diakses Minggu, 8 Oktober 2017 pukul 22.51 WIB. 
kunjungan kerjanya di Kepulauan Seribu, Jakarta Utara, pada 27 September 2016, diunggah oleh Buni Yani pada tanggal 6 Oktober 2016 di akun Facebooknya. ${ }^{4}$ Video itu sebelumnya sudah diedit dan kemudian ditambahkan kata-kata yang berbau provokatif bahwa Ahok telah menista agama! Tak lama berselang heboh pun terjadi. Berkali-kali Ahok didemo oleh massa dan menuntutnya mundur dari jabatan gubernur. Massa juga mendesak Ahok dihukum berat!

Setelah menjalani serangkaian persidangan dalam kasus penistaan agama, pada Selasa 9 Mei 2017, Hakim Dwiarso memvonis Ahok bersalah dan dihukum kurungan penjara selama dua tahun. ${ }^{5}$

Ketika Ahok menjadi korban fitnah, Ahok mengutip tulisan Goenawan Mohamad yang berjudul stigma, "stigma itu bermula dari fitnah... dusta yang terus-menerus diulang akan menjadi kebenaran." 6 Ahok sendiri mendapatkan simpati dari Ikrar Nusa Bhakti, seorang peneliti Lembaga Ilmu Pengetahuan Indonesia (LIPI), yang meminta majelis hakim untuk tidak bertindak diskriminatif dalam menangani kasus Ahok.7 Bahkan dosen hukum pidana Universitas Indonesia, Eva Ahyani Djulfa mengatakan bahwa siding pengadilan Ahok menggunakan saksi-saksi jaksa yang disebut Tim Pengacara Ahok sebagai de auditu, yaitu tidak melihat, tidak mendengar, dan tidak hadir saat Ahok menyampaikan pidatonya di Kepulauan Seribu. ${ }^{8}$ Bivitri Susanti dari Lembaga Pusat Studi Hukum dan Kebijakan (PSHK) menegaskan bahwa pasal penistaan agama seharusnya tidak ada dalam hukum Indonesia. ${ }^{9}$ Hal ini juga didukung oleh Ismael Hanani, peneliti Setara Institute yang mengatakan bahwa aturan dalam kasus penistaan agama dianggap sebagai pasal karet dan melanggar konsep HAM yang melindungi kebebasan individu termasuk dalam menafsirkan

\footnotetext{
Republika.co.id, 23 November 2016. Diakses 12 Oktober 2017 pukul 21.50 WIB.

Tribunnews.com Jakarta, 9 Mei 2017. Diakses 12 Oktober 2017 pukul 21.54 WIB.

BBC.com, 25 April 2017. Diakses 12 Oktober 2017 pukul 22.05 WIB.

Tempo.co, 13 Desember 2016. Diakses 12 Oktober 2017 pukul 22.15 WIB.

BBC.com, 9 Mei 2017. Diakses 12 Oktober 2017 pukul 22.00 WIB.

9 Tempo.co, 10 Mei 2017. Diakses 12 Oktober 2017 pukul 22.10 WIB.
} 
keyakinannya. ${ }^{10}$

Kasus Ahok yang didakwa dan divonis bersalah dalam kasus penistaan agama menyedot perhatian dunia internasional. Parlemen Belanda menyatakan hukuman terhadap Ahok sebagai serangan langsung terhadap kebebasan. ${ }^{11}$ Amnesty International berpendapat vonis bersalah dan penahanan Ahok akan menodai reputasi Indonesia dalam toleransi. ${ }^{12}$ The Guardian juga mengatakan bahwa hukuman terhadap Ahok sebagai ujian bagi toleransi dan pluralisme agama di Indonesia. ${ }^{13}$

Kasus tentang diskriminasi ini seharusnya menjadi satu bahan refleksi pemimpin-pemimpin agama di tingkat nasional, agar ke depan persoalan diskriminasi ini berkurang bahkan tidak terjadi lagi di negeri ini. Hal ini membutuhkan pemikiran-pemikiran yang bisa langsung diterapkan dalam konteks Indonesia. Artikel ini adalah salah satu bahan refleksi untuk menemukan solusi dari persoalan diskriminasi di Indonesia.

\section{Hukum Kasih dalam Perspektif Kristen}

Istilah "Hukum Kasih" yang dimaksud dalam kajian ini adalah hukum yang paling utama dan terutama di dalam kehidupan etis orang Kristen, yaitu "'Kasihilah Tuhan, Allahmu, dengan segenap hatimu dan dengan segenap jiwamu dan dengan segenap kekuatanmu dan dengan segenap akal budimu, dan kasihilah sesamamu manusia seperti dirimu sendiri." (Luk. 10:27). Ada hubungan erat yang terkait dari hukum ini, orang yang mengasihi Tuhan pasti mengasihi sesama manusia. Seperti yang dikatakan rasul Yohanes, "Jikalau seorang berkata: "Aku mengasihi Allah," dan ia membenci saudaranya, maka ia adalah pendusta, karena barangsiapa tidak mengasihi saudaranya yang dilihatnya, tidak mungkin

\footnotetext{
10 BBC.com Indonesia, 9 Mei 2017. Diakses 12 Oktober 2017 pukul 22.00 WIB.

11 BBC.com Indonesia, 10 Mei 2017. Diakses 12 Oktober 2017 pukul 22.18 WIB.

12 Ibid.

13 BBC.com Indonesia, 9 Mei 2017. Diakses 12 Oktober 2017 pukul 22.00 WIB.
} 
mengasihi Allah, yang tidak dilihatnya" (1Yoh. 4:20). Seperti yang dikatakan oleh Drs. Henk Ten Napel bahwa orang yang telah mengasihi manusia, dianggap telah mengasihi Allah (Mat. 25:31-46). ${ }^{14}$

Kasih di dalam kajian ini bukanlah tentang perasaan kasih sayang emosional belaka, tetapi satu sikap pro-aktif untuk melakukan satu kebaikan kepada orang lain. Josh McDowell mengatakan bahwa jika seseorang mengasihi sesama manusia dengan kasih sejati, orang itu tidak akan membunuhnya atau mencuri barang miliknya, bahkan tidak akan berzinah dengannya (Rm. 13:9). ${ }^{15}$ Artinya kasih itu jauh dari sikap mementingkan diri sendiri dan dapat dipraktekkan secara spontan, tanpa aturan baku. Bultmann mengatakan bahwa ciri khas kasih muncul di dalam kebebasan dan spontanitas, tidak diatur secara kekal. ${ }^{16}$

Alkitab menjelaskan tentang hal ini dalam Injil Markus, ketika Yesus menyembuhkan orang pada hari Sabat, hari yang dikhususkan untuk orang Israel tidak melakukan kegiatan apapun. Aturan menguduskan hari Sabat, termasuk menyembuhkan orang sakit, membuat kasih kepada sesama yang kehilangan kebebasannya. Tetapi Yesus berkata, "Manakah yang diperbolehkan pada hari Sabat, berbuat baik atau berbuat jahat, menyelamatkan nyawa orang atau membunuh orang?" (Mrk. 3:4). Dari pernyataan ini, Yesus memberikan prinsip yang paling utama yaitu bahwa nyawa manusia lebih penting daripada soal mengindahkan peraturan hari Sabat. Yang disorot dalam kasus ini bukan memilih antara aturan ibadah atau etika, tetapi memilih antara hidup atau mati. ${ }^{17}$

Perumpamaan Orang Samaria yang baik hati adalah pengajaran Yesus tentang bagaimana cara menerapkan hukum kasih kepada sesama manusia. Peristiwa yang terjadi dalam Lukas 10:25-37 sangat mirip

\footnotetext{
14 Drs. Henk Ten Napel, Jalan yang Lebih Utama Lagi (Jakarta: BPK Gunung Mulia, 1991), 39.

15 Josh McDowell, Pola Hidup Kristen (Malang: Gandum Mas, 2002).

16 Drs. Henk Ten Napel, Jalan Yang Lebih...., 36.

$17 \quad$ Ibid, 33.
} 
dengan peristiwa yang dicatat dalam Markus 12:28-34, walaupun berada dalam dua situasi yang berbeda. Ketika diamati, pertanyaan yang diajukan kepada Yesus dalam dua catatan Injil tersebut merujuk kepada hal yang sama, yaitu tentang hukum kasih. Berarti hal ini menggambarkan satu situasi yang terjadi dalam masyarakat Yahudi pada masa itu yaitu kurangnya mengasihi sesama. Tetapi hanya Lukas yang menceritakan kisah terkenal tentang "Orang Samaria yang baik hati". ${ }^{18}$

Kata yang diterjemahkan "sesama" berasal dari kata dalam Bahasa Yunani "plesion" yang berarti seseorang yang dekat (lih. Kis. 7:27). Kata ini berasal dari kata dalam bahasa Ibrani "rea" yang berarti seseorang dengan siapa seseorang memiliki sesuatu untuk dilakukan. Orang-orang Yahudi menafsirkan kata itu dalam arti terbatas, berarti sesama Yahudi atau seseorang di komunitas religius yang sama. Mereka secara khusus mengecualikan orang Samaria dan orang bukan Yahudi dari kategori ini.

Dari penjelasan ini terlihat bahwa diskriminasi sosial sudah terjadi pada masa pelayanan Yesus di bumi. Orang-orang Yahudi menganggap orang-orang Samaria menjadi orang-orang kelas dua dalam hal suku, agama dan ras. Sehingga dalam pengajaran-Nya Yesus selalu mengajak setiap murid-Nya untuk meninggalkan diskriminasi dalam masyarakat. Yesus bukan hanya mengajar, tetapi Ia mempraktekkan dalam kehidupan pelayanan-Nya. Yesus bergaul dengan orang-orang berdosa, orang-orang miskin bahkan juga bergaul dengan perempuan Samaria (Yoh. 4).

Dalam kisah perumpamaan tentang "orang Samaria yang baik hati", Yesus menceritakan tentang seseorang yang dirampok di jalan sepi yang menuju Yerikho. Yesus tidak menceritakan tentang ras dan pekerjaan orang yang dirampok ini, karena ini bukan fokus pengajarannya. Walaupun ada banyak penafsir yang berasumsi bahwa orang yang dirampok ini adalah orang Yahudi.

18 Pat and David Alexander, The Lion Handbook to the Bible (Oxford: Lion Hudson Pic, 2009), 609. 
Tempat terjadinya perampokan adalah jalan perlintasan dari Yerusalem ke Yerikho. Daerah yang berkelok-kelok sangat berbahaya dan sangat sepi, sehingga menjadi tempat favorit para perampok. Menurut Yerome, salah seorang bapa gereja, jalan perlintasan itu tetap disebut "jalan merah atau jalan darah."19 Hal inilah yang membuat korban perampokan tergeletak sendiri tanpa adanya pertolongan segera.

Perumpamaan tentang orang Samaria yang baik hati menggambarkan tentang tiga orang yang mewakili tiga jenis manusia yang memberikan respon terhadap korban kejahatan. Tiga orang itu adalah seorang Imam, seorang Lewi dan seorang Samaria. Tiga jenis manusia ini hendak dijelaskan tentang makna yang sesungguhnya dari sesama manusia.

Jenis manusia pertama adalah seorang imam. Seorang imam seringkali didefinisikan sebagai golongan rohaniawan tingkat atas. ${ }^{20}$ Seorang imam adalah seorang yang membaca dan menafsirkan Kitab Suci dan yang melayani umat Allah di Bait Suci. Seorang yang seharusnya mengetahui dan melaksanakan hakekat kasih.

Tetapi dalam kisah perumpamaan ini telah gagal menjadi seorang yang memiliki kedudukan untuk menolong korban perampokan tersebut.

Jenis manusis kedua adalah seorang Lewi. Orang Lewi adalah golongan keluarga imam. Orang-orang yang diajarkan prinsip dan pola pelayanan bagi umat Allah sejak masa kecilnya. Orang-orang yang seharusnya sudah fasih di dalam melaksanakan huum kasih. Tetapi seluruh didikan pelayanan ini tidak membuat hati nurani tergerak untuk melakukan pertolongan bagi sesama yang sedang menderita. Dalam perumpamaan ini, orang Lewi mengulangi tindakan imam tersebut.

Jenis manusia ketiga adalah orang Samaria. Meskipun orang Samaria, seperti orang Yahudi, menganggap hukum itu suci, orang

19 William Barclay, Pemahaman Alkitab Setiap Hari: Injil Lukas, BPK Gunung Mulia, 2005.

20 Dr. B. J. Boland, Tafsiran Injil Lukas (Jakarta: BPK Gunung Mulia, 2001), 272. 
Yahudi menganggap mereka sebagai sampah - tak tersentuh. ${ }^{21}$ Di antara ketiga orang dalam perumpamaan ini, Orang Samaria adalah orang yang diprediksi paling tidak mungkin untuk menawarkan pertolongan kepada orang yang sedang mengalami permasalahan ini. Tetapi orang Samaria ini melakukannya. Padahal orang Samaria ini memiliki alasan yang kuat untuk tidak menolong orang ini: pertama, orang Samaria sudah dicap sebagai orang jahat karena keturunannya. Kedua, orang Samaria dilarang untuk bergaul dengan orang Yahudi. Tetapi semua asusmi itu dipatahkan oleh orang Samaria itu, hanya dialah satu-satunya yang bersedia untuk menolong.

Orang Samaria ini memiliki sisi kemanusiaan di dalam dirinya, dan ketika ia melihat orang itu, "tergeraklah hatinya oleh belas kasihan." (Luk. 10:33). Imam dan orang Lewi memiliki hati yang mengeras terhadap salah seorang dari bangsanya sendiri, namun orang Samaria ini terbuka hatinya dengan belas kasihan melihat kesusahan orang lain yang tidak sebangsa dengan dia. Ketika dia melihat seorang korban perampokan yang sedang menderita, dia menaruh belas kasihan kepadanya, dan tidak pernah mempertimbangkan asal negaranya. Meskipun korban perampokan ini seorang Yahudi, orang ini adalah seorang manusia, dan seorang manusia yang dalam kesengsaraan, dan orang Samaria belajar untuk menghormati semua orang; karena itu orang Samaria ini mengasihani yang menjadi korban perampokan, karena dia sendiri menginginkan dan berharap untuk dikasihani seperti itu. Cinta kasih yang besar ditemukan dalam diri orang Samariaitu.

Orang Samaria inilah yang disebut oleh Yesus sebagai sesama manusia bagi korban perampokan ini. Ada pelajaran luhur dari perumpamaan ini, yaitu seringkali orang yang mengalami diskriminasi adalah orang-orang yang selalu menjadi sesama bagi orang-orang yang menderita. Orang Samaria ini membuktikannya: pertama, ia yang adalah

21 Pat and David Alexander, The Lion Handbook to the Bible (Oxford: Lion Hudson Pic, 2009), 610. 
seorang bidat, tetapi ia memiliki kasih Allah di dalam hatinya. Kedua, ia seorang yang ditolak oleh orang Yahudi, namun justru mengasihi sesama. Kesimpulan dari perumpamaan Orang Samaria yang baik hati adalah bahwa Yesus mau menegaskan bahwa sesama manusia yang "nyata" adalah orang yang melakukan hal yang penuh kasih kapan pun dan di mana pun terjadi, terlepas dari permusuhan atau antagonisme terdalam. ${ }^{22}$

\section{Prinsip-prinsip Hukum Kasih}

Dalam perumpamaan Orang Samaria ini, ada beberapa prinsip yang bisa diterapkan di dalam kehidupan beragama di Indonesia untuk menekan tingkat diskriminasi. Sehingga keharmonisan kehidupan berbangsa dan bertanah air di Indonesia dapat kembali dinikmati oleh masyarakat Indonesia.

Prinsip pertama adalah dengan melihat hakikat kasih itu sendiri. Kasih bergembira melihat kebaikan yang ada di dalam diri seseorang dan kasih juga mengharapkan sesuatu yang terbaik terjadi untuk diri orang tersebut (1Kor. 13:5-7). Dengan definisi ini, maka kasih sebenarnya mengatasi segala perbedaan suku, budaya, dan agama. Ini juga yang menjadi keyakinan Mahatma Gandhi bahwa diskriminasi hanya bisa dihentikan kalau kesadaran manusia ditingkatkan untuk mengenal kekuatan Hukum Kasih dalam semua segi kehidupan. ${ }^{23}$

Dalam perumpamaan Orang Samaria yang baik hati ini yang disorot adalah sikap bukan motifnya. Orang Samaria memiliki ketaatan untuk melakukan hukum kasih dibandingkan imam dan orang Lewi yang seringkali hanya mengajarkan dan membicarakannya saja. Rasa belas kasihannya yang membuat orang Samaria mengambil tindakan untuk menolong orang yang menderita. Belas kasihan dari Orang

\footnotetext{
22 Ibid, 610.

23 M. K. Gandhi, Damai adalah Satu-satunya Jalan: Nir-kekerasan - Suatu Kekuatan Dahsyat (Jakarta: BPK Gunung Mulia, 2009), 66.
} 
Samaria ini mampu mengatasi prasangka rasialnya terhadap orang Yahudi.

Abdurrahman Wahid atau biasa dipanggil Gus Dur adalah Presiden Republik Indonesia yang berjuang untuk melawan diskriminasi dalam masa pemerintahannya. Ada satu prinsip yang dipegang Gus Dur: "urusan agama adalah urusan personal kita dengan Tuhan. Urusan suku, adalah urusan kita dengan keluarga. Namun kita juga punya tanggung jawab sebagai manusia." 24 Dengan kata lain hukum kasih menawarkan suatu patokan yang mutlak, suatu kriteria utama yang dengannya usaha manusia dalam membangun suatu dunia baru yang lebih baik dapat diukur. Seperti yang diungkapkan oleh Macgregor bahwa hukum kasih bisa memberikan suatu cara pandang dan kritik yang berharga bagi etika sosial demi menata dunia sekarang ini. 25

Orang-orang yang memiliki belas kasihan adalah orang-orang yang memiliki bela rasa yang luar biasa dan dapat ditularkan. Hidupnya menjadi saluran kasih Allah - membawa damai. Seperti yang sering dikatakan oleh Thomas Merton, "Kemurahan dengan kemurahan di dalam kemurahan (Mercy with Mercy within Mercy)." 26 Belas kasihan inilah yang akan menutupi perbedaan di antara keberagaman yang ada di Indonesia, baik etnis maupun agama. Bersama pemerintah, semua elemen masyarakat akan mampu untuk membuat keharmonisan hidup dalam keberagaman terjalin kembali di bumi Indonesia.

Diskriminasi adalah suatu kejahatan sosial yang terjadi secara luas dan membawa dampak pada banyak orang. Diskriminasi itu sudah sangat mengakar dalam kehidupan peradaban manusia. Sehingga tidak mudah mencabut pola pikir diskriminatif dalam kehidupan bermasyarakat termasuk di Indonesia. Diperlukan orang-orang yang

\footnotetext{
24 www.muslimmoderat.net, 31 Oktober 2016. Diakses Sabtu 21 Oktober 2017 pukul 11.30 WIB.

25 G. H. C. Macgregor, Damai Adalah Satu-satunya Jalan: Relevansi dari Suatu Idealisme yang Mustahil (Jakarta: BPK Gunung Mulia, 2009), 45.

26 Ibid, 151.
} 
berani mengambil tanggung jawab ini, seperti orang Samaria ini.

Sejarah manusia modern membuktikan bahwa ada orang-orang yang berani mengambil tangggung jawab untuk melawan diskriminasi. Dimulai dari India, yaitu seorang yang bernama Mohandas K. Gandhi yang dikenal dengan Mahatma yang artinya berjiwa besar. Bagaimana Mahatma Gandhi melawan diskriminasi yang terjadi di negaranya dengan hukum kasih, melawan tanpa melakukan kekerasan. ${ }^{27}$ Kemudian ada juga Dr, Martin Luther King Jr., seorang rohaniawan terdidik yang menjadi pendeta Gereja Baptis Dexter Avenue di Montgomery yang melawan diskriminasi ras negro di Amerika Serikat. ${ }^{28}$ Orang-orang yang berani mengambil tangggungjawab untuk melawan diskriminasi dalam masyarakat akan selalu menemukan cara-cara yang mulia.

Mencari kepentingan sendiri atau kepentingan golongan adalah pemicu utama terjadinya praktek diskriminasi. Karena seringkali kepentingan-kepentingan pribadi dan golongan ini dibungkus dengan isu-isu dan tindakan-tindakan diskriminatif terhadap pribadi atau golongan yang menjadi "saingan" golongan tersebut. Oleh karena itu penting ditanamkam kerelaan untuk berkorban bagi kesejahteraan rakyat Indonesia. Hal yang bisa menjadi indikator bagi kesediaan mengambil tanggung jawab adalah berani membuat keputusan yang menyerang kebijakan diskriminatif. Hal ini pun dilakukan oleh Pangeran Mohammed bin Salman, Putera Mahkota Arab Saudi, yang bertekad menghapuskan sisa-sisa ekstremisme dengan segera. Bahkan ia menegaskan bahwa, "kami ingin hidup yang normal. Sebuah kehidupan dengan agama yang diwujudkan menjadi toleransi, menjadi tradisi keramahan kami." 29

\footnotetext{
27 Glenn Smiley, Damai Adalah Satu-satunya Jalan: Bagaimana Nir-Kekerasan Bekerja (Jakarta: BPK Gunung Mulia, 2009), 96.

$28 \quad$ Ibid, 97.

29 www.BBC-Indonesia, 25 Oktober 2017. Diakses Sabtu, 11 November 2017 pukul 17.40 WIB.
} 
Keberanian pemimpin dalam mengambil tanggung jawab untuk merumuskan kebijakan publik akan mampu mengikis perbedaan suku, agama dan ras. Biasanya perbedaan-perbedaan ras dan agama ini diperuncing karena memiliki kepentingan lain. Hal ini ditegaskan oleh Gerald Bray, "Konflik yang dihasilkan oleh perbedaan itu biasanya disebabkan oleh alasan lain yang sebenarnya tidak ada hubungannya dengan perbedaan tersebut." 30

Dalam perumpamaan "Orang Samaria yang baik hati" ini ditunjukkan bahwa belas kasihan adalah isu utama, bukan tentang pertimbangan ras dan agama. Gerald Bray menegaskan hal ini, "tidak ada alasan kita memperlakukan orang berbeda dengan rasnya, kita harus melawan keras prinsip rasis yang merupakan memori hidup yang diturunkan manusia awal peradaban." 31

Mempraktekkan hukum kasih adalah bentuk perjuangan yang paling berat terutama karena seseorang dituntut untuk bersedia mengalami kesulitan bahkan ancaman kematian, tanpa membalasnya dengan kekerasan, dan karena orang itu menolak semua bentuk kepentingan pribadi. Dalam pengertian yang sebenarnya, orang-orang yang mempraktekkan hukum kasih tidak berjuang demi kepentingan sendiri atau kepentingan kelompok tertentu, tetapi mereka melakukannya karena kebenaran objektif yang dipercayainya, dan untuk semua manusia. Thomas Merton meringkaskan bahwa mempraktekkan hukum kasih tidak diperuntukkan demi terjadinya pertobatan dari kejahatan pada kebaikan, tetapi demi perbaikan hubungan dan rekonsiliasi. ${ }^{32}$

Pengajaran agama bukan hanya sekadar untuk dihafalkan dan diajarkan, tetapi yang terpenting adalah praktek dari ajaran itu. Manusia dinilai bukan atas dasar pengakuan iman yang diikrarkan tetapi atas

\footnotetext{
30 Gerald Bray, God is Love (Illinois: Crossway, 2012), 337.

$31 \quad$ Ibid, 336.

32 Thomas Merton, Damai Adalah Satu-satunya Jalan: Berbahagialah Mereka yang Lemah Lembut (Jakarta: BPK Gunung Mulia, 2009), 76.
} 
dasar kehidupan yang dijalani. Ketika para pemimpin agama di Indonesia menekankan umat untuk melakukan ajaran kasih dalam agama mereka, maka diskriminasi akan kehilangan kekuatannya untuk menghancurkan keharmonisan hidup di Indonesia. Ketika semua masyarakat bisa saling mengasihi tanpa memandang suku, agama dan ras, maka pengamalan sila ketiga dari Pancasila, yaitu Persatuan Indonesia dapat terwujud.

\section{Hukum Kasih Landasan Bersama Agama-agama}

Ajaran cinta kasih adalah ajaran universal, di mana semua agama mengajarkan kasih sebagai aksi dalam kehidupan bermasyarakat. Hukum kasih bukan hanya merupakan landasan etis dari kekristenan, tetapi juga merupakan landasan agama-agama yang lain. Agama Hindu mengajarkan bahwa puncak dari kepercayaan kepada Tuhan Yang Maha Esa adalah penyatuan jiwa kepada dengan Sang Pencipta yang disebut dengan Jivanmukti. Hasil dari Jivanmukti adalah mengalirnya kasih sayang tanpa pamrih. Dalam suasana batin seperti inilah umat Hindu dapat menjauhkan kehidupan diskriminatif dengan menjalankan hukum kasih. ${ }^{33}$ Seperti yang diajarkan oleh Gandhi bahwa tindakan nondiskriminatif menuntut adanya dasar metafisik dan keagamaan yang kuat, baik di dalam sikap maupun di dalam Tuhan. ${ }^{34}$

Dalam agama Buddha ajaran tentang cinta kasih berasal dari Sang Buddha sendiri. Hal ini kemudian menjadi pegangan hidup yang dilaksanakan oleh para umatnya. Ajaran tentang cinta kasih tertuang dalam prinsip Metta Paramita yaitu sifat-sifat luhur cinta kasih tanpa keinginan untuk memiliki, yang ditujukan kepada semua makhluk tanpa membeda-bedakan ras, bangsa dan agama. ${ }^{35}$ Dari ajaran tentang cinta

\footnotetext{
33 A. A. Yewangoe, Agama dalam Dialog: Kerukunan Umat Beragama sebagai Tantangan dan Persoalan (Jakarta: BPK Gunung Mulia, 2003), 71.

34 Thomas Merton, Damai Adalah Satu-satunya Jalan: Berbahagialah Mereka yang Lemah Lembut (Jakarta: BPK Gunung Mulia, 2009), 76.

35 Ibid., 76.
} 
kasih ini, agama Buddha mengajarkan umatnya agar senantiasa melandaskan segala kehidupan dan kepentingan hidupnya dalam bermasyarakat berlandaskan kasih sayang.

Raja Asoka di India mengamalkan ajaran cinta-kasih Sang Buddha dalam pemerintahan kerajaannya yang melahirkan kebijakan nondiskriminatif bagi masyarakat yang dipimpinnya. Semua agama yang hidup pada masa itu diperlakukan sama, seperti terpahat dalam “Prasasti Batu Kalinga No. XXII Raja Asoka. Dalam prasasti itu antara lain kita temukan kalimat berikut: "... janganlah kita hanya menghormati agama sendiri dan mencela agama orang lain tanpa suatu dasar yang kuat. Sebaliknya agama orang lain pun hendaknya dihormati atas dasardasar tertentu. Dengan berbuat demikian kita telah membantu agama kita sendiri untuk berkembang di samping menguntungkan pula agama orang lain..."36

Agama Islam juga mengajarkan tentang hukum kasih. Hal ini dibuktikan dengan diadakannya konferensi yang diselenggarakan oleh Akademi Kerajaan dan Institut Aal-Bayt pada bulan September 2007, dengan tema "Kasih di dalam Al Quran." Konferensi yang digagas oleh 138 cendikiawan, ulama dan intelektual Muslim memperlihatkan bentuk akhir dari dokumen yang berisi Sebuah "Persamaan di antara Kami dan Kamu." ${ }^{37}$

Dokumen yang menetapkan adanya kata bersama antara umat Islam dan Kristen tersebut ditanda tangani oleh setiap denominasi, dan kelompok pemikiran Islam. Setiap negara atau wilayah Islam besar di dunia terwakili dalam pesan yang disingkat menjadi kata bersama. Dan pesan tersebut ditujukan kepada pemimpin, dan gereja di seluruh dunia. Dalam pesan tersebut juga dinyatakan bahwa sesungguhnya umat Islam dan Kristen sama-sama mengakui adanya Allah yang esa dan kedua

\footnotetext{
$36 \quad$ Ibid., 75.

37 www.acommonword.org, Pendahuluan Bagi Sebuah Persamaan ("A Common Word")

di Antara Kami dan Kamu, 13 Oktober 2006, 1.
} 
agama sama-sama diperintahkan untuk mengasihi Allah dan sesamanya, "Kasihilah Tuhan Allahmu dengan segenap hatimu dan dengan segenap jiwamu. Dan kasihilah sesamamu manusia seperti dirimu sendiri." Bunyi kata bersama itu ada dalam kedua kitab suci agama itu, dan bukan merupakan usaha mengkompromikan ajaran agama-agama yang mereduksikan nilai-nilai agama-agama itu.

Dalam ajaran Islam mengasihi sesama adalah bagian yang penting dan integral dalam iman kepada Allah dan kasih kepada Allah. Bahkan ditegaskan dalam ajaran Islam bahwa tanpa kasih kepada sesama tidak ada iman yang benar kepada Allah dan tidak ada kebenaran, seperti yang dikatakan oleh Nabi Muhammad SAW: “Tidak ada seorang pun dari kamu memiliki iman sampai kamu mengasihi saudaramu sebagaimana kamu mengasihi dirimu sendiri." Bahkan ajaran Islam mengatakan bahwa kasih kepada sesama tidak cukup hanya melalui empati, simpati dan doa formal. Tetapi harus ada tindakan nyata yaitu kemurahan dan pengorbanan diri. Karena Tanpa memberikan sesama apa yang kita sendiri kasihi, kita tidak benar-benar mengasihi Allah atau sesama. ${ }^{38}$

Dasar dari persamaan dan pengertian hukum kasih ini sudah ada. Yaitu bagian dari prinsip yang sangat mendasar dari kedua kepercayaan: kasih kepada Allah yang Maha Esa dan kasih kepada sesama manusia. Prinsip-prinsip ini ditemukan berulang-ulang di dalam teks-teks kitab suci agama Islam dan kitab suci agama Kristen. Pentingnya kasih kepada Allah, dan pentingnya kasih kepada sesama manusia dalam hukum kasih, dengan demikian menjadi dasar yang sama dalam pengajaran etis agama Islam dan pengajaran etis agama Kristen. Hal ini ditegaskan juga oleh Abdullah bin Sulaeman Al-Manea, anggota Dewan Cendekiawan Senior Arab Saudi, seperti yang dilansir Surat Kabar Kuwait, Al Anba', pada hari Jumat 10 November 2017 bahwa Islam adalah agama toleransi dan belas kasih, bukan kekerasan, intoleransi atau terorisme. Al-Manea juga menekankan bahwa umat Islam harus menyebarkan Islam yang

$38 \quad$ Ibid., 12. 
benar dan mengikuti tradisi Nabi Muhammad SAW untuk memperlakukan orang-orang yang berbeda agama secara toleran. ${ }^{39}$

Pengakuan bersama tentang hukum kasih menjadi penting bagi umat Islam dan Kristen, bukan hanya karena keduanya memiliki garis tradisi yang dekat, namun Islam dan Kristen merupakan agama-agama yang dipeluk oleh banyak masyarakat di dunia. Artinya, apabila ada kedamaian antara kedua agama tersebut, maka kedamaian dunia sudah hampir dapat dipastikan terjadi. Hubungan Islam dan Kristen yang harmonis sudah pasti dapat menjadi motivasi bagi semua agama-agama untuk hidup bersama dengan damai.

Apabila kita melihat lebih jauh pada agama-agama di luar Islam dan Kristen, pengakuan adanya "hukum kasih" sebenarnya bukan hanya ada pada agama Islam, Kristen dan Yahudi yang memiliki akar tradisi yang dekat, namun juga terdapat pada agama-agama lain. Jadi, agamaagama sesungguhnya memiliki tugas mulia untuk menciptakan kedamaian di bumi, sebagaimana dikatakan oleh Hans Kung, “tidak mungkin ada kedamaian tanpa kedamaian di antara agama-agama. Sebagai seorang yang beragama, tidaklah patut berbicara tentang kedamaian tanpa berusaha untuk hidup damai dengan agama-agama lain."

Ajaran tentang hukum kasih dalam setiap agama adalah sebuah landasan yang kokoh untuk mencapai kehidupan yang harmonis di tengah masyarakat Indonesia yang majemuk. Yang menjadi pekerjaan rumah adalah bagaimana hukum kasih yang menjadi hakekat ajaran setiap agama di Indonesia menjadi sebuah landasan yang dapat dipakai oleh pemerintah untuk merumuskan setiap kebijakan yang tidak berbau diskriminatif. Dan perlu komitmen dan kreativitas dari setiap umat beragama di Indonesia untuk mewujudkan hal ini.

39 www.CNN-Internasional, 10 November 2017. Diakses Sabtu, 11 November 2017 pukul 17.18 . 
Jika kasih terhadap Allah dan kasih terhadap sesama manusia menjadi dasar untuk semua dialog yang dilakukan, maka konflik bisa diselesaikan dengan hati yang penuh kasih, dan dengan tetap memegang hukum Allah untuk menjelaskan keyakinan dengan penuh hormat dan welas asih kepada orang yang berbeda agama. Hal ini jelas akan menyingkirkan sisi gelap dari diskriminasi, khususnya dalam perumusan kebijakan di Indonesia. Karena dengan dasar hukum kasih ini, semua agama mengakui dalam keyakinan imannya bahwa semua manusia sama di hadapan Allah. Sehingga sebagai landasan iman dari semua agama, kebijakan yang akan dirumuskan harus jauh dari unsur diskriminatif.

Hukum kasih yang mencakup kasih kepada Allah dan kasih kepada sesama manusia juga harus nyata dalam kehidupan umat beragama yang berbeda dalam hidup sehari-hari, dalam hubungan atasan dan bawahan, guru dengan murid, antartetangga, sesama pedagang kaki lima, pelayanan kesehatan dan pendidikan, dan semua aspek kehidupan lainnya. Kasih kepada Allah dan kasih kepada sesama seharusnya membuat masyarakat Indonesia yang majemuk tidak membeda-bedakan orang dan melakukan kebaikan tanpa memandang suku, agama, jenis kelamin atau status sosialnya. Intinya hukum kasih harus menjadi sebuah landasan yang kuat untuk semua warga negara Indonesia merasakan menjadi tuan di negeri sendiri. Artinya Indonesia yang adalah rumah bersama dari berbagai suku, ras, agama dan golongan menjadi rumah yang menjamin kehidupan bermasyarakat jauh dari unsur dan tindakan-tindakan diskriminatif. Semua warga negara Indonesia yang majemuk itu adalah satu tanah air, satu bangsa, satu bahasa, yaitu Indonesia.

\section{Penerapan Hukum Kasih di Indonesia}

Doktrin utama setiap agama adalah mengasihi Tuhan dengan segenap hati. Memandang Tuhan sebagai yang maha kuasa, dan sangat sempurna, yang wajib untuk dihargai dengan segala kebesaran-Nya, dan 
juga wajib dilayani dengan pengabdian diri yang tulus oleh setiap umat manusia. Umat Tuhan harus mengasihi Tuhan lebih dari segala-galanya. Maka, kasih umat kepada Tuhan pasti akan tulus, hangat dan bersungguh-sungguh. Kasih inilah yang akan mendorong setiap umat dapat mengasihi sesamanya dengan cara melakukan semua yang baik. Ketika hal ini dapat terwujud, maka setiap pribadi yang terlibat di dalam merumuskan kebijakan-kebijakan public yang berdampak pada semua, akan dimotivasi oleh semangat karena mengetahui bahwa semua manusia di hadapan Tuhan sama nilainya. Tuhanlah yang menciptakan keberagaman, supaya di dalam keberagaman itu semua manusia dapat melihat kemuliaan Tuhan.

Ketika semua kebijakan dirumuskan tanpa prasangka-prasangka jahat terhadap satu golongan tertentu, atau satu agama tertentu atau pun atas satu suku tertentu, maka dapat diyakini kebijakan yang dihasilkan jauh dari unsur-unsur diskriminatif. Hal ini ditegaskan oleh Howard Thurman, "tidak akan ada harapan untuk memenuhi mimpi demokrasi dalam hidup kita masa kini kecuali keinginan untuk pemisahan ini dihilangkan." 40

Berlomba untuk menjadi pionir dalam mempraktekkan hukum kasih ini seharusnya menjadi semangat agama-agama. Proses penghilangan diskriminasi tidak bisa dilakukan dalam waktu semalam. Tetapi semua kita bisa mengambil komitmen untuk melakukannya. Kebebasan memilih yang dimiliki oleh umat manusia seharusnya menjadi alternatif yang diambil agar hukum kasih menjadi acuan hidup umat beragama di Indonesia. Tindakan semacam ini membutuhkan disiplin tinggi untuk mengakhiri praktek diskriminasi di Indonesia. Semuanya harus dilakukan dengan penuh kesadaran bahwa Allah sedang mengamati semua yang memiliki komitmen ini.

Berbicara kasih adalah hal penting, tetapi menerapkan kehidupan kasih terlebih penting lagi. Ketika semua umat beragama mengharapkan

$40 \quad$ Ibid, 269. 
sebuah perdamaian dalam kehidupan bermasyarakat, dibutuhkan kerendahan hati untuk mempraktekkan hukum kasih. Thomas Merton meyakini bahwa manusia yang adalah ciptaan Tuhan pada dasarnya tidak jahat, bahkan di dalam diri manusia ada kemampuan untuk mewujudkan perdamaian, asalkan tercipta satu kondisi yang memungkin hal itu terjadi, yaitu dengan memilih kasih dan bukannya kebencian dan kecurigaan. ${ }^{41}$

\section{Penutup}

Diskriminasi akan selalu membawa dampak perpecahan di dalam kehidupan berbangsa dan bernegara. Sudah seharusnya setiap pribadi mengevaluasi praktek kehidupan bermasyarakat dan beragama, agar tejalin sikap toleransi yang kuat. Dengan sikap yang bisa saling menghormati, saling menghargai dan saling mengasihi akan terjalin keharmonisan di dalam kemajemukan masyarakat di Indonesia.

Pembelajaran yang penting dari perumpamaan orang Samaria yang baik hati adalah Allah tidak menginginkan kemajemukan menjadi alasan untuk tidak peduli kepada sesama manusia. Sesama manusia di dalam sudut pandang Allah adalah semua manusia ciptaan-Nya tanpa memandang suku, agama dan ras. Allah yang menciptakan keberagaman di bumi ini, menginginkan keberagaman menjadi suatu keharmonisan yang unik yang diikat oleh rasa saling mengasihi. Sehingga sudah seharusnya dalam setiap permusan kebijakan, unsur-unsur diskriminatif tidak menjadi acuan lagi, tetapi yang menjadi landasan dalam perumusan kebijakan adalah hukum kasih. Satu landasan etis untuk mengasihi sesama manusia tanpa memandang latar belakang suku, agama dan ras. Sehingga akan terbentuk masyarakat Indonesia yang harmonis dalam kemajemukan.

\footnotetext{
41 Thomas Merton, Damai Adalah Satu-satunya Jalan: Berbahagialah Mereka yang Lemah Lembut (Jakarta: BPK Gunung Mulia, 2009), 81.
} 
Kasih adalah karakter Allah. Sudah seharusnya manusia yang adalah ciptaan-Nya mempraktekkan karakter Allah untuk saling mengasihi sesama manusia. Setiap orang dari suku, agama dan ras manapun yang membutuhkan pertolongan adalah sesama manusia yang dimaksud oleh perumpamaan ini. Bantuan seorang terhadap yang lain seharusnya seluas kasih Allah. 